\title{
Enhancement of Extracellular Pullulanase Production by Raoultella planticola DSMZ 4617 Using Optimized Medium Based on Sago Starch
}

\author{
Siew Ling Hii ${ }^{1, \#}$, Tau Chuan Ling ${ }^{2}$, Rosfarizan Mohamad ${ }^{1,3}$ and Arbakariya B. Ariff ${ }^{1,3, *}$
}

${ }^{1}$ Laboratory of Industrial Biotechnology, Institute of Bioscience, Universiti Putra Malaysia, 43400 Serdang, Selangor, Malaysia; ${ }^{2}$ Department of Process and Food Engineering, Faculty of Engineering, Universiti Putra Malaysia, 43400 Serdang, Selangor, Malaysia; ${ }^{3}$ Department of Bioprocess Technology, Faculty of Biotechnology and Biomolecular Sciences, Universiti Putra Malaysia, 43400 Serdang, Selangor, Malaysia and ${ }^{\#}$ Present address: Department of Bioscience and Chemistry, Faculty of Engineering and Science, Universiti Tunku Abdul Rahman, 53300 Setapak, Kuala Lumpur, Malaysia

\begin{abstract}
Enhancement of pullulanase production by Raoultella planticola DSMZ 4617 using optimized medium formulation was investigated in batch fermentation using $500-\mathrm{mL}$ shake flask. The fermentations were carried out, firstly, to search for a suitable cultivation medium for enzyme production and followed by the evaluations on the influence of carbon and nitrogen sources and also initial culture pHs on the secretion of pullulanase by this bacterium. The modified mineral Czapek medium was found suitable to produce substantially high activity of pullulanase (320 times higher) as compared to 'Ohba-Ueda' medium. This bacterium was found superior in pullulanase production using sago starch and peptone as carbon and nitrogen sources, respectively. Using the optimized medium, the bacterium produced $0.95 \mathrm{U} / \mathrm{mL}$ of pullulanase at initial culture $\mathrm{pH}$ of 7 and incubation temperature of $30^{\circ} \mathrm{C}$.
\end{abstract}

Key Words: Pullulanase, Raoultella planticola DSMZ 4617, submerged fermentation, sago starch.

\section{INTRODUCTION}

Pullulanase (EC 3.2.1.41) is a direct debranching enzyme that catalyzes the hydrolysis of $\alpha-1,6$-glucosidic bonds of unmodified substrate, for example, amylopectin and/or glycogen and related polymers. The main function of pullulanase was to improve the efficiency of starch saccharification process. It is because pullulanase would specifically hydrolyze the branch points in the amylopectin residues whereas the glucoamylase has only to hydrolyze the linear 1,4- $\alpha$-glucosidic linkages when pullulanase and glucoamylase are simultaneously used during saccharification process. As a result, the maximum dextrose levels achieved are higher [1]. Therefore, the use of a debranching enzyme would speed the overall saccharification process and reduce the total amount of glucoamylase that is required for complete conversion process. The practical advantage of using pullulanase together with glucoamylase is that less glucoamylase activity would be used. This will allow a reduction in the use of glucoamylase up to $60 \%$ and therefore less enzyme catalyzed polymerization of D-glucose to isomaltose takes place [2].

Varieties of carbon-containing substrates have been used as carbon source for pullulanase fermentation by microorganisms, for example, pullulan [3], maltose [3, 4] and starch $[5,6]$. Overall, the use of starch as a carbon source was found to yield the pullulanase which is intermediate to high

*Address correspondence to this author at the Department of Bioprocess Technology, Faculty of Biotechnology and Biomolecular Sciences, Universiti Putra Malaysia, 43400 Serdang, Selangor, Malaysia; Tel: +603 89467516; Fax: +603 89467510; E-mail: arbarif@biotech.upm.edu.my in comparison to other carbon sources. The rate of pullulanase synthesis was also appeared to vary with the nature of nitrogen source and most of the studies on the influence of nitrogen source on pullulanase production were performed using organic nitrogen sources such as yeast extract, peptone, tryptone, trypticase, casamino acids and corn steep liquor $[5,7,8]$.

Pullulanase fermentation by gram positive bacteria has been well-reported and commercial varieties of pullulanase are mainly derived from either Bacillus acidopullulyticus or Klebsiella planticola [9] or Bacillus deramificans (expressed in Bacillus licheniformis) [10]. However, information on pullulanase synthesis by a gram negative bacterium, such as, Raoultella planticola, which has been reported as superior pullulanase producer, is very limited. The present study was undertaken to investigate the nutrients requirements and cultural conditions for enhancement of pullulanase production from this bacterium. Preliminary, selection of the suitable medium formulation for pullulanase fermentation by $R$. planticola was conducted. Subsequently, the feasibility of using different types of starch as carbon source for the production of pullulanase was carried out. Influence of different types of nitrogen source and initial culture $\mathrm{pH}$ were also investigated.

\section{MATERIALS AND METHODS}

\section{Microorganism and Inoculum Preparation}

The pullulanase-producing bacterium, Raoultella planticola DSMZ 4617, was used in this study. The strain was stored at $-80^{\circ} \mathrm{C}$ in $30 \%(\mathrm{v} / \mathrm{v})$ glycerol. For inoculum preparation, five loops of culture from the stock was sub-cultured 
into the red pullulan agar (Megazyme, Ireland). A single colony from the red pullulan agar was inoculated into 500 $\mathrm{mL}$ Erlenmeyer flask containing nutrient broth (Merck, Germany) and incubated at $30^{\circ} \mathrm{C}$ for $24 \mathrm{~h}$ to obtain an initial cell concentration with optical density of around 0.5 read at $550 \mathrm{~nm}$. This culture was used for inoculum $(10 \% \mathrm{v} / \mathrm{v})$ for all fermentations carried out in this study.

\section{Selection of Cultivation Medium}

Brandt et al. [11] found that extracellular pullulanase by a Klebsiella sp. was obtained in a modified mineral Czapek medium with maltose as a carbon source. On the other hand, Ohba and Ueda [12] reported that pullulanase from Aerobacter aerogenes RS-1 was produced in a medium similar to the modified mineral Czapek medium with potato starch as a carbon source and ammonium acetate as a nitrogen source. The feasibilities of using modified mineral Czapek and 'Ohba-Ueda' media were investigated in this study and the media were prepared according to the methods as described by Brandt et al. [11] and Ohba and Ueda [12], respectively (Table 1). Experiment to study the effect of different carbon sources was carried out by replacing the carbon sources, according to the need of each experiment. Gelatinized starches were prepared by heating starch slurry to slightly above $70^{\circ} \mathrm{C}$. The effect of various organic nitrogen sources, i.e., meat extract, tryptone, tryptose, yeast extract, bacteriological peptone and peptone (Difco Laboratories, USA) was studied with sodium nitrate as the inorganic nitrogen source. Subsequently, the effect of different inorganic nitrogen sources (ammonium sulfate and ammonium acetate - Merck, Germany) on pullulanase production was performed by replacing sodium nitrate and peptone was used as an organic nitrogen source. Unless stated elsewhere, all replacements were performed with the same concentration of each nitrogen source.

Table 1. Composition of the Selected Growth and Production Media

\begin{tabular}{|c|c|c|c|}
\hline \multicolumn{2}{|c|}{$\begin{array}{c}\text { Modified Mineral Czapek } \\
\text { Medium (Brandt et al., 1976) }\end{array}$} & \multicolumn{2}{c|}{$\begin{array}{c}\text { 'Ohba-Ueda' Medium } \\
\text { (Ohba and Ueda, 1982) }\end{array}$} \\
\hline Compound & $(\%$ w/v) & Compound & $(\%$ w/v) \\
\hline \hline $\mathrm{K}_{2} \mathrm{HPO}_{4}$ & 0.1 & $\mathrm{CH}_{3} \mathrm{COONH}_{4}$ & 0.8 \\
$\mathrm{NaNO}_{3}$ & 0.5 & $\mathrm{~K}_{2} \mathrm{HPO}_{4}$ & 0.2 \\
$\mathrm{MgSO}_{4} .7 \mathrm{H}_{2} \mathrm{O}$ & 0.05 & $\mathrm{MgSO}_{4} .7 \mathrm{H}_{2} \mathrm{O}$ & 0.075 \\
$\mathrm{KCl}^{2}$ & 0.05 & $\mathrm{FeSO}_{4} \cdot 7 \mathrm{H}_{2} \mathrm{O}$ & 0.005 \\
$\mathrm{FeSO}_{4} .7 \mathrm{H}_{2} \mathrm{O}$ & 0.001 & $\mathrm{Peptone}^{2}$ & 0.03 \\
$\mathrm{Peptone}_{\mathrm{Maltose}}$ & 0.8 & Potato starch & 1.5 \\
\hline
\end{tabular}

* Source of chemicals: $\mathrm{K}_{2} \mathrm{HPO}_{4}, \mathrm{KCl}$ (Univar Ajar Chemical, Australia); $\mathrm{NaNO}_{3}$, $\mathrm{MgSO}_{4} .7 \mathrm{H}_{2} \mathrm{O}, \mathrm{FeSO}_{4} .7 \mathrm{H}_{2} \mathrm{O}, \mathrm{CH}_{3} \mathrm{COONH}_{4}$ (Merck, Germany); maltose (Sigma Aldrich, USA), potato starch (local hypermarket, Malaysia)

\section{Submerged Fermentation}

The production of pullulanase was carried out as submerged fermentation using 500-mL Erlenmeyer flask containing $200 \mathrm{~mL}$ of liquid medium. In all experiments, initial
$\mathrm{pH}$ of medium was adjusted to 7.0 using $1 \mathrm{~N} \mathrm{HCl}$, except for the study on the effect of initial culture $\mathrm{pH}$ on growth and pullulanase production where the initial $\mathrm{pH}$ of medium was adjusted to the required value prior to sterilization. The flasks were incubated at $30^{\circ} \mathrm{C}$ and agitated at $250 \mathrm{rpm}$ in an orbital shaker (B. Braun Biotech International, Germany). All fermentations were carried out in triplicate and the results presented were average values.

\section{Analytical Procedures}

Pullulanase activity was determined by measuring the enzymatic release of reducing sugars during incubation with pullulan (from Aureobasidium pullulans; Sigma-Aldrich Chemie Gmbh). The reaction mixture contained $1 \%$ pullulan in $0.02 \mathrm{M}$ sodium phosphate buffer, $\mathrm{pH} 6.9$ and a sample of the enzyme, in a final volume of $1 \mathrm{~mL}$. After incubation at respective temperatures for $30 \mathrm{~min}$, concentration of reducing sugar was determined using 3, 5-dinitrosalicylic acid method where the absorbance was read at $540 \mathrm{~nm}$ [13]. One unit of pullulanase activity is defined as the amount of enzyme required to produce $1 \mu \mathrm{mol}$ reducing sugar (equivalent to maltotriose) per minute under the assay conditions.

Concentration of starch was determined colorimetrically [14] on the basis of iodine starch complex color with some modification. Supernatant from a culture broth was mixed with $0.1 \mathrm{M}$ phosphate buffer ( $\mathrm{pH} 7.2,60 \mu \mathrm{L}), 5 \mathrm{M} \mathrm{NaCl}(200$ $\mu \mathrm{L}), 1 \mathrm{M} \mathrm{HCl}(40 \mu \mathrm{L})$, iodine reagent $(50 \mu \mathrm{L})$ and distilled water $(10 \mathrm{~mL})$. The absorbance for the mixture was then read at $625 \mathrm{~nm}$.

Dry cell weight was determined by filtration and oven drying method. Samples (after treatment with $\alpha$-amylase, 0.2 $\mathrm{mL}$ ) were filtered through a pre-weighed $0.2 \mu \mathrm{m}$ cellulose nitrate membrane filter (Whatman) by using a vacuum pump. The cells were then dried in an oven at $95^{\circ} \mathrm{C}$ until a constant weight was achieved.

\section{RESULTS AND DISCUSSION}

\section{Selection of Cultivation Medium for Growth and Pullu- lanase Production}

The performance of pullulanase production by $R$. planticola DSMZ 4617 using different cultivation media (modified mineral Czapek medium and 'Ohba-Ueda' medium) is summarized in Table 2. Pullulanase production by $R$. planticola DSMZ 4617 in modified mineral Czapek medium (0.32 $\mathrm{U} / \mathrm{mL}$ ) was about 320 times higher than that obtained in fermentation using 'Ohba-Ueda' medium $(0.001 \mathrm{U} / \mathrm{mL})$.

Pullulanase yield was much better (137.8 unit of enzyme produced per unit of substrate utilized) when the fermentation was conducted using modified mineral Czapek medium than 'Ohba-Ueda' medium. The stimulatory effect of maltose on the induction of pullulanase production by microorganism has been reported and discussed in several past researches. According to Brandt et al. [11], synthesis of pullulanase can be enhanced by pullulan, maltotriose and maltose. Gomes et al. [15] also proved that among the various carbon sources tested, maltose was the most effective for the production of pullulanase by Rhodothermus marinus. Moreover, several studies reported that the production of pullulanase, in both Klebsiella pneumoniae and E. coli K-12 carrying the cloned pulA gene, was stimulated by growth in the presence 
of maltose and positively regulated by MalT protein, activator of the maltose regulon $[3,16]$. Hence, the pullulanase was overproduced and secreted into the culture medium.

Growth measured as cell concentration under 'OhbaUeda' medium was much lower $(0.26 \mathrm{~g} / \mathrm{L})$ than fermentation using modified mineral Czapek medium (0.72 g/L). The presence of high concentration of organic nitrogen source, i.e., $0.8 \mathrm{~g} / \mathrm{L}$ of peptone, in modified mineral Czapek medium as compared to $0.03 \mathrm{~g} / \mathrm{L}$ peptone in 'Ohba-Ueda' medium might play an important role in cell growth and pullulanase synthesis inside the cell before it is secreted into the culture medium [17]. Suzuki and Chishiro [18] reported that pullulanase synthesis by B. steorothermophilus KP 1064 was stimulated by organic nitrogen sources. Medium containing only ammonium sulfate or ammonium acetate did not enhance amylases production by B. cereus BQ 10-S1 Spo [19]. Since the production of pullulanase by $R$. planticola DSMZ 4617 in modified mineral Czapek medium was significantly higher as compared to 'Ohba-Ueda' medium, this medium was chosen and applied in the subsequent experiments.

\section{Production of Pullulanase Using Different Types of Starch}

The time-course of pullulanase fermentation by $R$. planticola DSMZ 4617 using starch as carbon source is given in Fig. (1A-C). The bacterium grew well in all types of starch used except for corn-based medium where the cell concentration was significantly lower than that in other starchcontaining media. Growth was rapid (specific growth rate $=$ $0.17 \mathrm{~h}^{-1}$ ) during the initial stages of the fermentation (10 to $16 \mathrm{~h}$ of cultivation) and reached a stationary phase after $48 \mathrm{~h}$, except for corn starch as cell growth ceased before level off (Fig. 1B). Marlida et al. [20] reported that due to starch composition (less amylopectin and high amylose content), corn starch was more resistant to enzyme action and therefore required much longer hydrolysis time before it can be 'consumed' by the microorganisms for biomass built-up.

The highest extracellular pullulanase production was found in fermentation using sago starch as the sole carbon source, with maximum pullulanase activity of approximately $0.95 \mathrm{U} / \mathrm{mL}$, followed by potato $(0.85 \mathrm{U} / \mathrm{mL})$, tapioca $(0.68$ $\mathrm{U} / \mathrm{mL}$ ) and corn $(0.14 \mathrm{U} / \mathrm{mL})$ (Table 3$)$. In all cases, pullulanase activity has not been detected during the early stages of fermentation (0-24 h) (Fig. 1A). Active enzyme production was only started during the later stages of exponential growth phase. Similar observations were also reported by many researchers who stated that pullulanase from Klebsiella sp. is initially localized to the outer membrane and is released into the medium when the cells have completed exponential growth $[3,21]$. In addition, the lowest production of pullulanase enzyme in corn-based medium $(0.14$ $\mathrm{U} / \mathrm{mL})$ may be related to the lowest cell production $(0.38$ $\mathrm{g} / \mathrm{L})$. The results obtained indicated that sago starch-based medium could be used as a favorable cultivation medium for the growth of culture and also enzyme production by $R$. planticola DSMZ 4617.

Among the four types of starch investigated, the highest yield (182 unit pullulanase/g starch) and productivity $(0.0079 \mathrm{U} / \mathrm{mL} \mathrm{h})$ was obtained when sago starch was used (Table 3). The variations in pullulanase production by $R$. planticola DSMZ 4617 in medium containing different types of starch might be due to the fact that starches from different sources differ in overall structure through size distribution of the granules, shape, amylose and lipid content, distribution of chain length in amylopectin and crystalline structure [22]. Moreover, lower degree of intermolecular association in sago starch granules might cause it to be easily hydrolyzed by enzymes [23], such as pullulanase. Protein content in sago starch is very low but is exceptionally high in soluble carbohydrates, therefore, sago starch could be as effective as other commercial starches used in fermentation industry [24].

From Fig. (1C), the estimated volume of starch slurry in the culture system containing potato, tapioca and sago starches decreased almost linearly after the pullulanase had been detected in the culture fluid and also outer surface of the cells. After $48 \mathrm{~h}$ of fermentation, there was no significant difference among the residual concentration of potato $(0.3$ $\mathrm{g} / \mathrm{L})$, tapioca $(0.1 \mathrm{~g} / \mathrm{L})$ and sago $(0.1 \mathrm{~g} / \mathrm{L})$ starches. The residual concentration of corn $(4.0 \mathrm{~g} / \mathrm{L})$ was significantly different from the others in which almost $70 \%$ of starch remained unconsumed even after $144 \mathrm{~h}$ of fermentation.

The maximum rate of starch hydrolysis $\left(-\mathrm{dS}_{\mathrm{dit}} \mathrm{max}\right)$, calculated by measuring the maximum tangent gradient of the curves when starch concentration was plotted against fermentation time, varied with the type of starches employed. The $-\mathrm{dS} / \mathrm{dt}_{\max }$ was approximately $0.191 \mathrm{~g} / \mathrm{L} / \mathrm{h}$ for potato starch, $0.237 \mathrm{~g} / \mathrm{L} / \mathrm{h}$ for tapioca starch, $0.208 \mathrm{~g} / \mathrm{L} / \mathrm{h}$ for sago starch and $0.032 \mathrm{~g} / \mathrm{L} / \mathrm{h}$ for corn starch, respectively. It is interesting to note that the reducing sugars were not detected in culture during the fermentation period, suggesting that the uptake of reducing sugars was faster than the release of residual reducing sugar from starch hydrolysis. This was one of the advantages of using starch as the carbon source for pullulanase production. The presence of glucose and other readily metabolizable sugars might repress pullulanase synthesis [11].

During the initial stages of fermentation (0-24 h), the culture $\mathrm{pH}$ was increased from $\mathrm{pH} 7$ to $\mathrm{pH}$ 9. The $\mathrm{pH}$ was slightly decreased when the cells started to release pullulanase onto the culture and at the same time the starch was hydrolyzed, indicating that the starch hydrolysis could be one of the hydrogen-producing processes [2]. Then, the culture $\mathrm{pH}$ started to increase to around $\mathrm{pH} 8.5$ after cell growth and production of extracellular pullulanase reached maximum levels.

This study clearly demonstrated that $R$. planticola DSMZ 4617 was a suitable microorganism for the production of pullulanase by using gelatinized sago starch as a carbon source. It has high ability to produce pullulanase enzyme during growth on sago starch as compared to maltose which has not been reported elsewhere. This is an attraction in reducing the overall production cost since sago starch is normally classified as cheap source of carbon (USD 0.5 per $\mathrm{kg}$ as supplied by Song Ngeng Sago Ind. (EM) Sdn Bhd, Malaysia) compared to maltose (USD 226 per $\mathrm{kg}$ as supplied by Sigma-Aldrich, USA). Furthermore, sago starch which is abundantly available in Malaysia [24], is an interesting alternative carbon source for pullulanase fermentation by this bacterium. During the fermentation process, $R$. planticola DSMZ 4617 offered an advantage of no protease being released (see Table 3) which implicates the versatile usage of 
this microorganism as pullulanase-producer with better enzyme stability.

\section{Nitrogen Requirements}

The time courses of pullulanase fermentation by $R$. planticola DSMZ 4617 using different types of organic and inorganic nitrogen sources are shown in Fig. (2) and the performance of each fermentation are summarized in Tables 4 and 5. The organic nitrogen source used greatly influenced both growth and pullulanase production (Table 4). For all types of organic nitrogen investigated, the fermentation time to reach maximum pullulanase activity was more than $120 \mathrm{~h}$ (Fig. 2A). Except meat extract and bacteriological peptone, all organic nitrogen sources tested were found to be capable of producing pullulanase enzyme extracellularly with activity more than $0.3 \mathrm{U} / \mathrm{mL}$. The highest pullulanase activity $(0.95 \mathrm{U} / \mathrm{mL})$ was detected in medium containing peptone, followed by tryptone, yeast extract, tryptose, meat extract and bacteriological peptone with the activity of $0.87 \mathrm{U} / \mathrm{mL}$, $0.40 \mathrm{U} / \mathrm{mL}, 0.36 \mathrm{U} / \mathrm{mL}, 0.24 \mathrm{U} / \mathrm{mL}$ and $0.18 \mathrm{U} / \mathrm{mL}$, respectively.

The yield of pullulanase produced based on utilized starch $\left(\mathrm{Y}_{\mathrm{P} / \mathrm{S}}\right)$ and productivity $(\mathrm{P})$ were significantly different for different types of organic nitrogen sources used. The highest yield $\left(\mathrm{Y}_{\mathrm{P} / \mathrm{S}}\right)\left(182 \mathrm{U}\right.$ enzyme $\left.\mathrm{g} \mathrm{starch}^{-1}\right)$ and maximum productivity $(\mathrm{P})(0.0079 \mathrm{U} / \mathrm{mL} \cdot \mathrm{h})$ was obtained in fermentation using peptone. Type of organic nitrogen source also greatly influenced the rate of hydrolysis of starch during cell growth and pullulanase production phase. Starch was hydrolyzed effectively in medium supplemented with tryptone or peptone as compared to other nitrogen sources (Fig. 2B). More than $40 \%$ of starch supplied still remained in the culture for fermentation using meat extract and bacteriological peptone even after $120 \mathrm{~h}$ of cultivation.

In order to investigate whether the culture produce the enzyme effectively or the production of enzyme is simply proportional to cell mass, the maximum activity of pullulanase was calculated based on a unit of cell weight $\left(\mathrm{P}_{\max } / \mathrm{X}_{\max }\right)$ [25]. From the results obtained (Table 4), all tested organic nitrogen sources could promote the growth of the culture $\left(X_{\max }=0.55 \mathrm{~g} / \mathrm{L}\right.$ to $\left.0.70 \mathrm{~g} / \mathrm{L}\right)$. The ability of the culture to produce pullulanase, however, decreased in medium containing bacteriological peptone, meat extract, yeast extract and tryptose with the ratio of $\mathrm{P}_{\max } / \mathrm{X}_{\max }$ in the range of 335 unit/g to 576 unit/g. The highest value of $\mathrm{P}_{\max } / \mathrm{X}_{\max }$ was achieved in medium containing peptone (1484 unit pullulanase/g cell) and thus indicated that peptone could be one of the favorable organic nitrogen sources that enhance the cell growth of the culture as well as the pullulanase production.

Table 2. Effects of Two Different Cultivation Media (Modified Mineral Czapek Medium and 'Ohba-Ueda' Medium) on Pullulanase Production by $R$. planticola DSMZ 4617 in Shake Flask Fermentation

\begin{tabular}{|c|c|c|}
\hline \multirow{2}{*}{ Parameters } & \multicolumn{2}{|c|}{ Medium } \\
\cline { 2 - 3 } & $\begin{array}{c}\text { Modified Mineral } \\
\text { Czapek }\end{array}$ & $\begin{array}{c}\text { 'Ohba- } \\
\text { Ueda' }\end{array}$ \\
\hline \hline $\mathrm{P}_{\max }(\mathrm{U} / \mathrm{mL})^{1}$ & $0.32^{\mathrm{a}}$ & $0.001^{\mathrm{b}}$ \\
$\mathrm{t}_{\mathrm{p}}(\mathrm{h})$ & $36^{\mathrm{b}}$ & $43^{\mathrm{a}}$ \\
$\mathrm{X}_{\max }(\mathrm{g} / \mathrm{L})^{1}$ & $0.72^{\mathrm{a}}$ & $0.26^{\mathrm{b}}$ \\
$\mathrm{t}_{\mathrm{x}}(\mathrm{h})$ & $36^{\mathrm{b}}$ & $42^{\mathrm{a}}$ \\
$\mathrm{S}\left(\mathrm{x} \mathrm{10} 0^{-3} \mathrm{~g} / \mathrm{mL}\right)$ & $2.36^{\mathrm{a}}$ & $1.48^{\mathrm{b}}$ \\
$\mathrm{P}\left(\mathrm{x} \mathrm{10} 0^{-3} \mathrm{U} / \mathrm{mL} \cdot \mathrm{h}\right)$ & $9.00^{\mathrm{a}}$ & $0.05^{\mathrm{b}}$ \\
$\mathrm{Y}_{\mathrm{P} / \mathrm{S}}(\mathrm{U}$ pullulanase/g starch $)$ & $137.8^{\mathrm{a}}$ & $0.7^{\mathrm{b}}$ \\
\hline
\end{tabular}

'Maximum value of pullulanase activity and cell concentrations were the highest values attained during cultivation.

${ }^{a-b}$ Mean values in the same row not followed by the same letter are significantly different $(\mathrm{P}<0.05)$

Among the three inorganic nitrogen compounds used, sodium nitrate and ammonium sulfate were found to be better than ammonium acetate for production of pullulanase by $R$. planticola DSMZ 4617 (Table 5). Sodium nitrate and ammonium sulfate highly support good growth of $R$. planticola DSMZ 4617 than ammonium acetate.

Table 3. Comparison of the Performance and Kinetic Parameter Value of Pullulanase Fermentation by $R$. planticola DSMZ 4617 in Shake Flask Using Different Types of Starch

\begin{tabular}{|c|c|c|c|c|}
\hline Parameters & Potato & Tapioca & Corn & Sago \\
\hline $\mathrm{P}_{\max }(\mathrm{U} / \mathrm{mL})$ & $0.85^{\mathrm{b}}$ & $0.67^{\mathrm{c}}$ & $0.14^{\mathrm{d}}$ & $0.95^{\mathrm{a}}$ \\
\hline $\mathrm{t}_{\mathrm{p}}(\mathrm{h})$ & $144^{\mathrm{a}}$ & $120^{\mathrm{b}}$ & $72^{\mathrm{c}}$ & $120^{\mathrm{b}}$ \\
\hline $\mathrm{X}_{\max }(\mathrm{g} / \mathrm{L})$ & $0.62^{\mathrm{a}}$ & $0.64^{\mathrm{a}}$ & $0.38^{\mathrm{b}}$ & $0.64^{\mathrm{a}}$ \\
\hline $\mathrm{S}\left(\mathrm{x} 10^{-3} \mathrm{~g} / \mathrm{mL}\right)$ & $4.90^{\mathrm{c}}$ & $5.10^{\mathrm{b}}$ & $1.48^{\mathrm{d}}$ & $5.23^{\mathrm{a}}$ \\
\hline $\mathrm{P}\left(\mathrm{x} 10^{-3} \mathrm{U} / \mathrm{mL} \cdot \mathrm{h}\right)$ & $5.93^{\mathrm{b}}$ & $5.60^{\mathrm{c}}$ & $1.96^{\mathrm{d}}$ & $7.92^{\mathrm{a}}$ \\
\hline $\mathrm{Y}_{\mathrm{P} / \mathrm{S}}(\mathrm{U}$ pullulanase/g starch) & $174.1^{\mathrm{b}}$ & $131.6^{\mathrm{c}}$ & $95.6^{\mathrm{d}}$ & $181.6^{\mathrm{a}}$ \\
\hline Maximum protease activity $(\mu \mathrm{g} / \mathrm{mL})$ & N.D. ${ }^{1}$ & N.D. & N.D. & N.D. \\
\hline
\end{tabular}

${ }^{\mathrm{a}-\mathrm{d}}$ Mean values in the same row not followed by the same letter are significantly different $(\mathrm{P}<0.05)$

${ }^{1}$ N. D. - Not Detectable. 

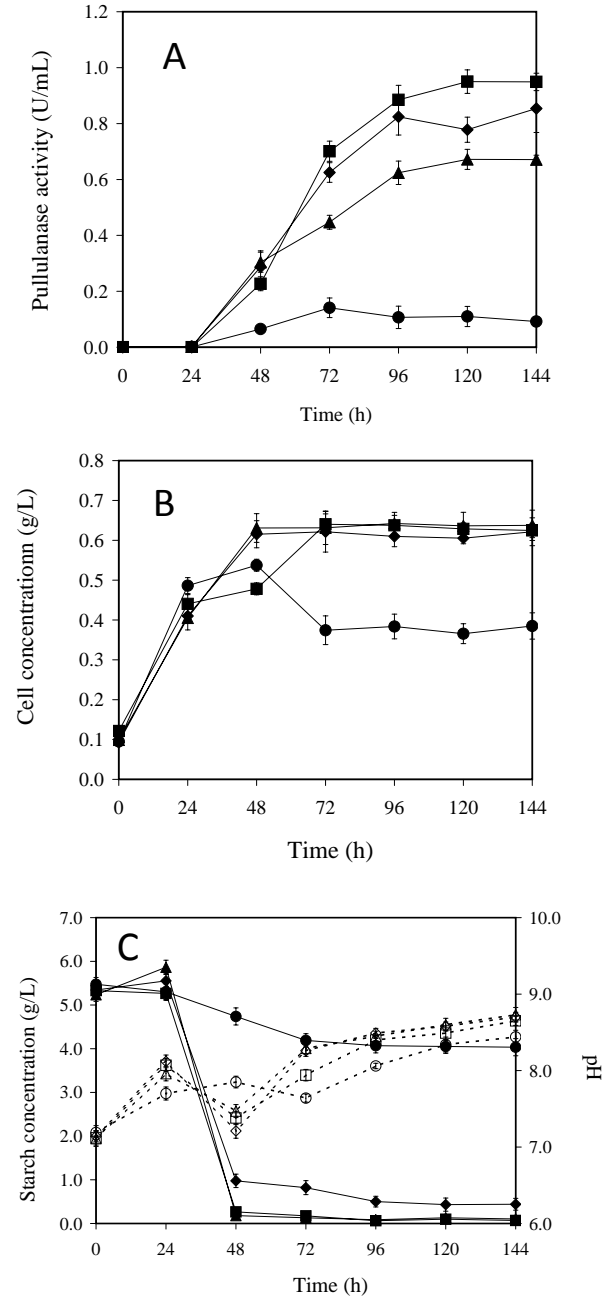

Fig. (1). Time course of pullulanase production by $R$. planticola DSMZ 4617 using starch as carbon source. (A), pullulanase activity; (B), growth profile; $(\mathbf{C})$ starch concentration (solid lines) and pH (dotted lines). Symbols represent: $(\diamond)$, potato starch; $(\boldsymbol{\Delta})$, tapioca starch; (), corn starch; (ם), sago starch. Error bars indicate the mean \pm standard deviation of triplicate.

The differences in the amount of amino acids content and/or type of amino acid present in different nitrogen sources might be one of the reasons why production of enzymes by microorganisms can be repressed or activated [26]. For example, Antranikian et al. [17] found that with the presence of organic nitrogen source in the cultivation medium, more than $90 \%$ of the enzyme was released into the culture fluid by Clostridium thermohydrosulfuricum DSM 567. Swamy and Seenayya [5] also reported that among the different nitrogen sources tested, peptone was found to be more preferred for extracellular and cell bound pullulanase production by Clostridium thermosulfurogenes SV9.

\section{Effect of Initial Culture pH}

The time courses of pullulanase fermentation by $R$. planticola DSMZ 4617 at different initial culture $\mathrm{pH}$ values are shown in Fig. (3) and the performance of each fermentation is given in Table 6. Different initial culture $\mathrm{pH}$ values greatly influenced the extracellular pullulanase production by $R$. planticola DSMZ 4617 (Fig. 3A). At initial culture pH between 5 to 8 , there was significant difference on extracellular pullulanase production, where the maximum activity detected was approximately $0.5 \mathrm{U} / \mathrm{mL}, 0.8 \mathrm{U} / \mathrm{mL}, 1.0 \mathrm{U} / \mathrm{mL}$ and $0.6 \mathrm{U} / \mathrm{mL}$ for $\mathrm{pH} \mathrm{5,} \mathrm{pH} 6, \mathrm{pH} 7$ and $\mathrm{pH} 8$, respectively. Thus, $R$. planticola DSMZ 4617 was found to be able to produce extracellular pullulanase at the initial $\mathrm{pH}$ of 6 to 8 . Ohba and Ueda [12] reported that the optimal range of initial $\mathrm{pH}$ for extracellular pullulanase production by Aerobacter aerogenes RS-1 was between $\mathrm{pH} 7$ to $\mathrm{pH}$ 9. dos-Santos et al. [27] also reported that the minimum initial culture $\mathrm{pH}$ to be set at 6 prior to the fermentation process, indicating that the Klebsiella oxytoca $\mathrm{P} 2$ under study performed well in that $\mathrm{pH}$ value.
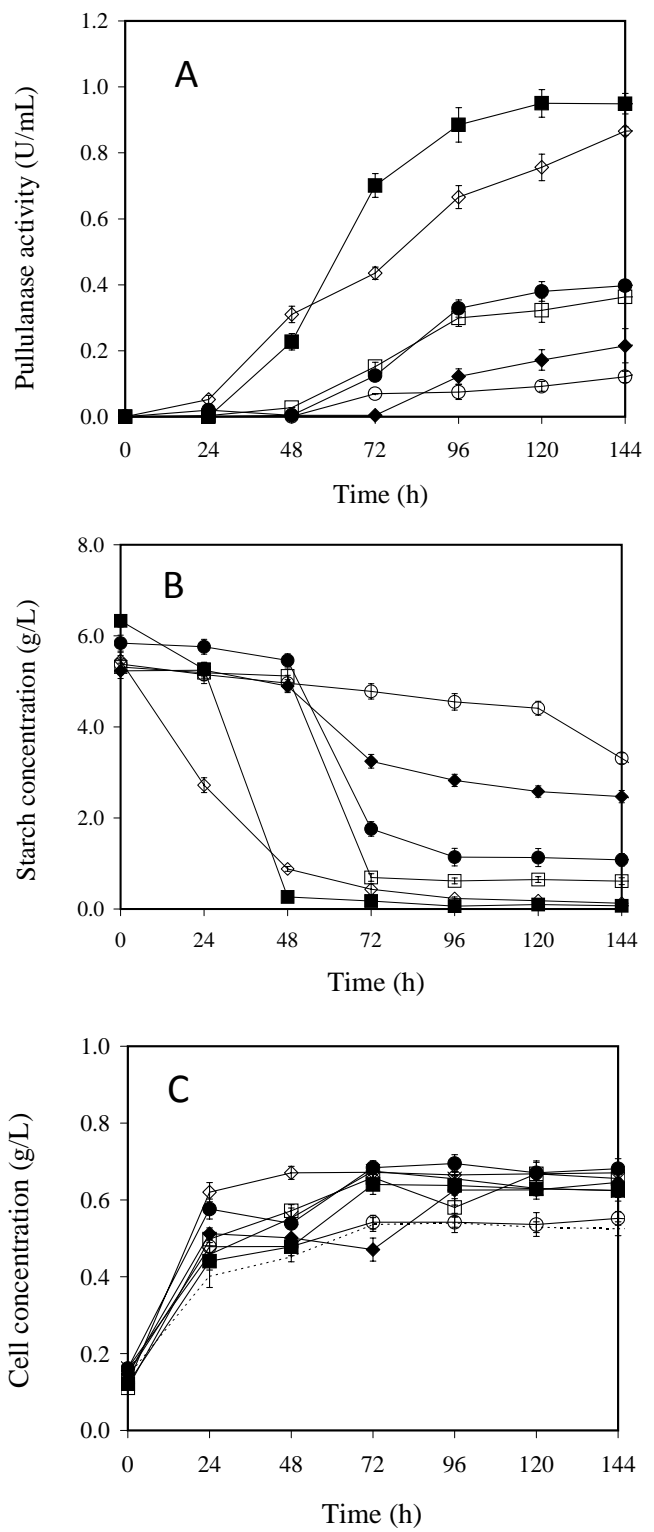

Fig. (2). Time course of pullulanase production by $R$. planticola DSMZ 4617 using various types of organic nitrogen source. (A), pullulanase activity; $(\mathbf{B})$, starch concentration and $(\mathbf{C})$, growth profile. Symbol: $(\diamond)$, meat extract; $(\diamond)$, tryptone; $(\square)$, tryptose; $(\mathbf{O})$, yeast extract; $(\bigcirc)$, bacteriological peptone; $(\mathbf{\square})$, peptone from meat. Error bars indicate the mean \pm standard deviation of triplicate.

Growth increased with increasing initial culture $\mathrm{pH}$ between 4 to 9 (Fig. 3B). There was no significant difference for growth between $\mathrm{pH} 5$ to 8 and growth reached a station- 

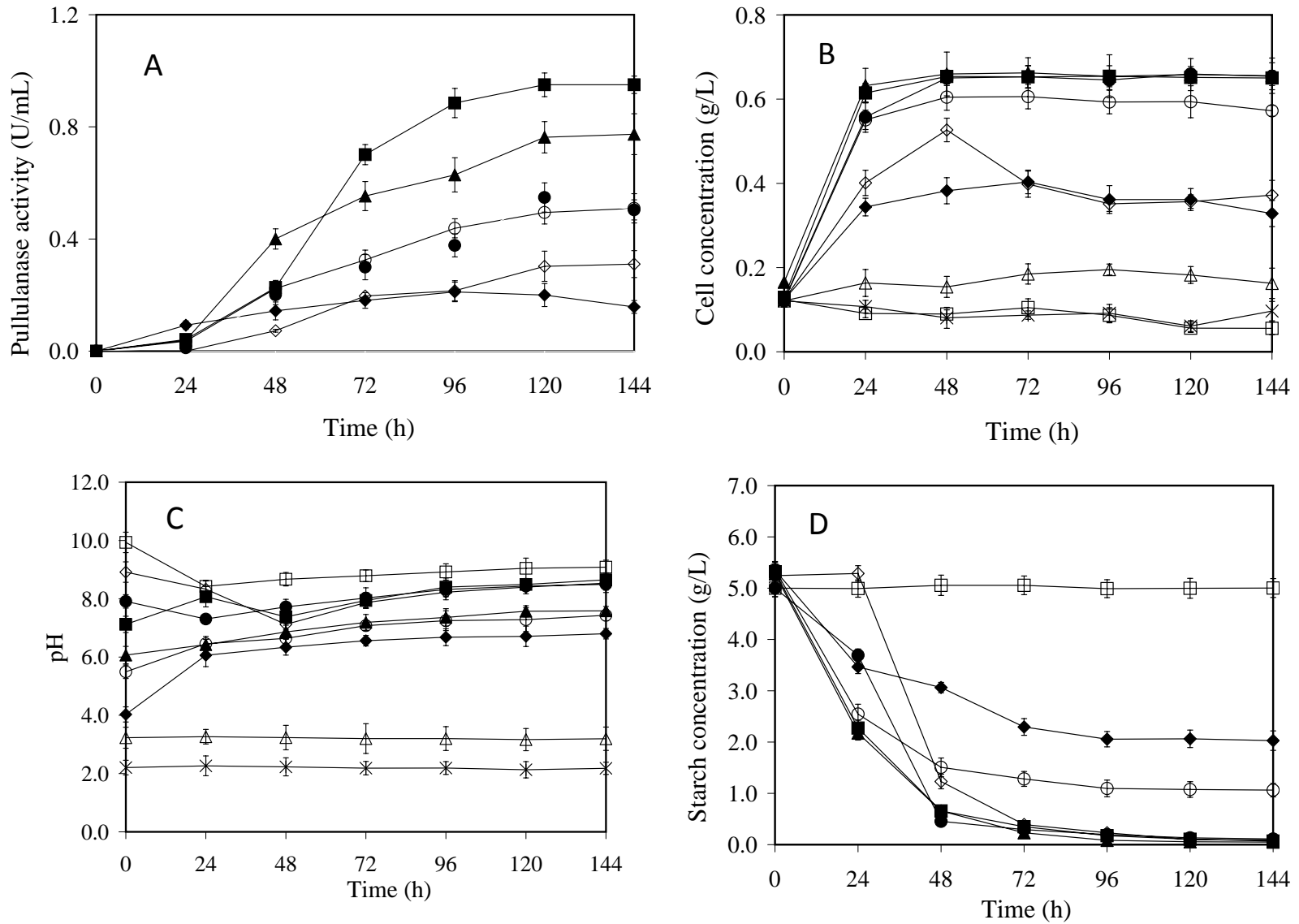

Fig. (3). Time course of pullulanase production by R. planticola DSMZ 4617 under different initial culture pH. (A), pullulanase activity; (B), growth profile; $(\mathbf{C}), \mathrm{pH}$ and $(\mathbf{D})$, starch concentration. Symbols: $(*), \mathrm{pH} 2 ;(\triangle), \mathrm{pH} 3 ;(\diamond), \mathrm{pH} 4 ;(\bigcirc), \mathrm{pH} 5 ;(\boldsymbol{\Delta}), \mathrm{pH} 6 ;(\boldsymbol{\square}), \mathrm{pH} 7 ;(\mathbf{\bullet}), \mathrm{pH}$ $8 ;(\diamond), \mathrm{pH} 9 ;(\square), \mathrm{pH} 10$. Error bars indicate the mean \pm standard deviation of triplicate.

Table 4. Comparison of the Performance and the Kinetic Parameter Value of Pullulanase Fermentation by $R$. planticola DSMZ 4617 in Shake Flask Using Different Types of Organic Nitrogen Source

\begin{tabular}{|c|c|c|c|c|c|c|}
\hline Parameters & Meat Extract & Tryptone & Tryptose & Yeast Extract & $\begin{array}{l}\text { Bacteriological } \\
\text { Peptone }\end{array}$ & Peptone \\
\hline $\mathrm{P}_{\max }(\mathrm{U} / \mathrm{mL})$ & $0.24^{\mathrm{b}, \mathrm{c}}$ & $0.87^{\mathrm{a}}$ & $0.36^{\mathrm{b}}$ & $0.40^{\mathrm{b}}$ & $0.18^{\mathrm{c}}$ & $0.95^{\mathrm{a}}$ \\
\hline$t_{p}(h)$ & $168^{\mathrm{a}}$ & $144^{\mathrm{b}}$ & $144^{\mathrm{b}}$ & $168^{\mathrm{a}}$ & $168^{\mathrm{a}}$ & $120^{\mathrm{b}}$ \\
\hline $\mathrm{t}_{\mathrm{x}}(\mathrm{h})$ & $144^{\mathrm{a}}$ & $144^{\mathrm{a}}$ & $120^{\mathrm{b}}$ & $95^{\mathrm{c}}$ & $144^{\mathrm{a}}$ & $72^{\mathrm{b}}$ \\
\hline $\mathrm{S}\left(\mathrm{x} 10^{-3} \mathrm{~g} / \mathrm{mL}\right)$ & $3.05^{\mathrm{d}}$ & $5.33^{\mathrm{b}}$ & $4.70^{\mathrm{c}}$ & $4.71^{\mathrm{c}}$ & $3.17^{\mathrm{d}}$ & $5.23^{\mathrm{a}}$ \\
\hline $\mathrm{P}\left(\mathrm{x} 10^{-3} \mathrm{U} / \mathrm{mL} \cdot \mathrm{h}^{-}\right)$ & $1.43^{\mathrm{d}}$ & $6.25^{\mathrm{b}}$ & $2.5^{\mathrm{c}}$ & $2.38^{\mathrm{c}}$ & $1.09^{\mathrm{e}}$ & $7.92^{\mathrm{a}}$ \\
\hline $\mathrm{Y}_{\mathrm{P} / \mathrm{S}}(\mathrm{U}$ pullulanase/g starch $)$ & $78^{\mathrm{d}}$ & $169^{\mathrm{b}}$ & $77^{\mathrm{e}}$ & $85^{\mathrm{c}}$ & $58^{\mathrm{f}}$ & $182^{\mathrm{a}}$ \\
\hline $\mathrm{P}_{\max } / \mathrm{X}_{\max }(\mathrm{U} / \mathrm{g}$ cell $)$ & $372^{\mathrm{e}}$ & $1343^{\mathrm{b}}$ & $539^{\mathrm{d}}$ & $576^{\mathrm{c}}$ & $335^{\mathrm{f}}$ & $1484^{\mathrm{a}}$ \\
\hline
\end{tabular}

${ }^{\mathrm{a}-\mathrm{f}}$ Mean values in the same row not followed by the same letter are significantly different $(\mathrm{P}<0.05)$.

ary phase after $120 \mathrm{~h}$ of cultivation with maximum cell concentration of approximately $0.65 \mathrm{~g} / \mathrm{L}$. No growth or pullulanase production was detected in medium with initial culture $\mathrm{pH}$ less than 4 or more than 9 , indicating that $R$. planticola DSMZ 4617 was neither an acidophilic nor alkalophilic pullulanase-producing bacterium.
The profiles of $\mathrm{pH}$ during pullulanase fermentation by $R$. planticola DSMZ 4617 at different initial culture pHs are shown in Fig. (3C). In fermentation with initial culture $\mathrm{pH}$ from 4 to $7, \mathrm{pH}$ was increased during the early stages of cultivation. In contrast to this, for initial culture $\mathrm{pH} 8$ and $\mathrm{pH} 9$, $\mathrm{pH}$ was reduced to around 7.5 before the pullulanase was 
Table 5. Comparison of the Performance and the Kinetic Parameter Value of Pullulanase Fermentation by $R$. planticola DSMZ 4617 in Shake Flask Using Different Types of Inorganic Nitrogen Source

\begin{tabular}{|c|c|c|c|}
\hline \multirow{2}{*}{ Parameters } & \multicolumn{3}{|c|}{ Inorganic Nitrogen Source } \\
\hline & Sodium Nitrate & Ammonium Sulfate & Ammonium Acetate \\
\hline $\mathrm{P}_{\max }(\mathrm{U} / \mathrm{mL})$ & $0.95^{\mathrm{a}}$ & $0.67^{\mathrm{c}}$ & $0.18^{\mathrm{c}}$ \\
\hline $\mathrm{t}_{\mathrm{p}}(\mathrm{h})$ & $120^{\mathrm{b}}$ & $144^{\mathrm{a}}$ & $120^{\mathrm{b}}$ \\
\hline $\mathrm{X}_{\max }(\mathrm{g} / \mathrm{L})$ & $0.64^{\mathrm{a}}$ & $0.68^{\mathrm{a}}$ & $0.45^{\mathrm{b}}$ \\
\hline $\mathrm{S}\left(\mathrm{x} 10^{-3} \mathrm{~g} / \mathrm{mL}\right)$ & $5.23^{\mathrm{b}}$ & $5.46^{\mathrm{a}}$ & $1.82^{\mathrm{c}}$ \\
\hline $\mathrm{P}\left(\mathrm{x} 10^{-3} \mathrm{U} / \mathrm{mL} \cdot \mathrm{h}\right)$ & $7.92^{\mathrm{a}}$ & $4.86^{\mathrm{b}}$ & $1.46^{\mathrm{c}}$ \\
\hline $\mathrm{Y}_{\mathrm{P} / \mathrm{S}}(\mathrm{U}$ pullulanase/g starch) & $181^{\mathrm{a}}$ & $128^{\mathrm{b}}$ & $96^{\mathrm{c}}$ \\
\hline
\end{tabular}

${ }^{\mathrm{a}-\mathrm{c}}$ Mean values in the same row not followed by the same letter are significantly different $(\mathrm{P}<0.05)$.

Table 6. Effect of Different Initial Culture pH Values on the Performance of Pullulanase Fermentation by $R$. planticola DSMZ 4617 in Shake Flask

\begin{tabular}{|c|c|c|c|c|c|c|c|c|}
\hline \multirow{2}{*}{ Initial pH } & \multicolumn{8}{|c|}{ Parameters } \\
\hline & $\begin{array}{c}\mathbf{P}_{\max } \\
(\mathbf{U} / \mathbf{m L})\end{array}$ & $\begin{array}{c}\mathbf{t}_{\mathbf{p}} \\
\text { (h) }\end{array}$ & $\begin{array}{l}\mathbf{X}_{\max } \\
(\mathrm{g} / \mathrm{L})\end{array}$ & $\begin{array}{c}\mathbf{t}_{\mathbf{x}} \\
(\mathbf{h})\end{array}$ & $\begin{array}{c}\mathrm{S} \\
\left(\times 10^{-3} \mathrm{~g} / \mathrm{mL}\right)\end{array}$ & $\begin{array}{c}\mathrm{P} \\
\left(\mathbf{x} 10^{-3} \mathrm{U} / \mathrm{mL} \cdot \mathrm{h}\right)\end{array}$ & $\begin{array}{c}\mathbf{Y}_{\mathrm{P} / \mathrm{S}} \\
(\mathrm{U} / \mathrm{g} \text { starch })\end{array}$ & $\begin{array}{r}P_{\max } / X_{\max } \\
(\mathrm{U} / \mathrm{g} \text { cell })\end{array}$ \\
\hline 4 & $0.21^{\mathrm{f}}$ & $96^{\mathrm{c}}$ & $0.40^{\mathrm{d}}$ & $72^{\mathrm{a}}$ & $3.29^{\mathrm{d}}$ & $2.20^{\mathrm{e}}$ & $64.1^{\mathrm{e}}$ & $523^{\mathrm{f}}$ \\
\hline 5 & $0.50^{\mathrm{d}}$ & $120^{\mathrm{b}}$ & $0.61^{\mathrm{b}}$ & $72^{\mathrm{a}}$ & $4.28^{\mathrm{c}}$ & $4.20^{\mathrm{d}}$ & $116.8^{\mathrm{c}}$ & $825^{\mathrm{d}}$ \\
\hline 7 & $0.95^{\mathrm{a}}$ & $120^{\mathrm{b}}$ & $0.66^{\mathrm{a}}$ & $72^{\mathrm{a}}$ & $5.23^{\mathrm{a}}$ & $7.92^{\mathrm{a}}$ & $181.6^{\mathrm{a}}$ & $1435^{\mathrm{a}}$ \\
\hline 8 & $0.55^{\mathrm{c}}$ & $120^{\mathrm{b}}$ & $0.65^{\mathrm{a}}$ & $72^{\mathrm{a}}$ & $4.90^{\mathrm{b}}$ & $4.57^{\mathrm{c}}$ & $111.8^{\mathrm{d}}$ & $843^{\mathrm{c}}$ \\
\hline 9 & $0.31^{\mathrm{e}}$ & $144^{\mathrm{a}}$ & $0.53^{\mathrm{c}}$ & $48^{\mathrm{b}}$ & $5.14^{\mathrm{a}}$ & $2.08^{\mathrm{e}}$ & $58.4^{\mathrm{f}}$ & $588^{\mathrm{e}}$ \\
\hline
\end{tabular}

${ }^{\mathrm{a}-\mathrm{f}}$ Mean values in the same column not followed by the same letter are significantly different $(\mathrm{P}<0.05)$.

Notes:

$\mathrm{P}_{\max }$ - Maximum extracellular pullulanase.

$\mathrm{t}_{\mathrm{p}} \quad$ - Time to reach maximum extracellular pullulanase.

$\mathrm{X}_{\max }$ - Maximum cell concentration.

$t_{x} \quad$ - Time to reach maximum cell concentration.

S - Concentration of substrates utilized.

$\mathrm{P}$ - Pullulanase productivity.

$\mathrm{Y}_{\mathrm{P} / \mathrm{S}}-$ Pullulanase yield.

detected in the culture fluid. In all cases, at the end of fermentation, the culture $\mathrm{pH}$ was in the range of $\mathrm{pH} 6$ to $\mathrm{pH} 9$. This indicates that the $\mathrm{pH}$ ranging from 6 to 9 was favorable for $R$. planticola DSMZ 4617 to secrete the enzyme outside the cells.

Starch hydrolysis rate increased with increasing initial culture $\mathrm{pH}$ and for medium with initial $\mathrm{pH}$ between 6 to 9 , no significant difference for amount of starch hydrolyzed was observed (Table 6). For medium with initial culture $\mathrm{pH}$ between 5 to 9 , more than $80 \%$ of starch was hydrolyzed for abundant cell growth and pullulanase production. At $\mathrm{pH}$ below 4 and above 9, growth and starch hydrolysis was very poor. The observed yield of pullulanase $\left(\mathrm{Y}_{\mathrm{P} / \mathrm{S}}\right)$ was significantly different between each of the $\mathrm{pH}$, as shown in the following sequence: $\mathrm{pH} 7>\mathrm{pH} 6>\mathrm{pH} 5>\mathrm{pH} 8>\mathrm{pH} 4>\mathrm{pH}$ 9. The value of $\mathrm{P}_{\max } / \mathrm{X}_{\max }$ was also higher in medium with initial culture $\mathrm{pH}$ between 5 to 8 where more than 800 unit of enzymes produced per unit of cells.

\section{CONCLUSION}

In batch fermentation experiments using sago starch and peptone as carbon and nitrogen sources, we proved that pullulanase production by $R$. planticola DSMZ4617 could be enhanced. The pullulanase activities were $67 \%$ higher when sago starch was used to replace maltose in fermentation medium. In addition, initial culture $\mathrm{pH}$ and incubation temperature also had strong effects on the cell growth and pullulanase production. By applying initial culture $\mathrm{pH}$ of 7 and incubation temperature of $30^{\circ} \mathrm{C}$ in medium containing sago starch and peptone, significant high activity of pullulanase could be produced by $R$. planticola DSMZ 4617. 


\section{ACKNOWLEDGEMENTS}

The author is indebted to Institute of Bioscience, Universiti Putra Malaysia (UPM), Malaysia for the research facilities, Ministry of Science, Technology and Innovation (MOSTI) Malaysia and NBD (project number: 09-03-03-005 BTK/ER/017) for the scholarship and research funding, respectively.

\section{REFERENCES}

[1] Jensen BD, Norman BE. Bacillus acidopullyticus pullulanase: applications and regulatory aspects for use in food industry. Proc Biochem 1984; 1: 397-400.

[2] Hebeda RE. Starches, sugars and syrups. In: Nagodawithana T, Reed G, Eds. Enzymes in food processing. New York: Academic Press Inc. 1993; pp. 321-346.

[3] Michaelis S, Chapon C, D'enfert C, Pugsley AP, Schwartz M. Characterization and expression of the structural gene for pullulanase, a maltose-inducible secreted protein of Klebsiella pneumoniae. J Bacteriol 1985; 164: 633-8.

[4] Gantelet H, Duchiron F. Purification and properties of a thermoactive and thermostable pullulanase from Thermococcus hydrothermalis, a hyperthermophilic archaeon isolated from a deep-sea hydrothermal vent. Appl Microbial Biotechnol 1998; 49: 770-7.

[5] Swamy MV, Seenayya G. Thermostable pullulanase and $\alpha$-amylase activity from Clostridium thermosulfurogenes SV 9-optimization of culture conditions for enzyme production. Proc Biochem 1996; 31: 157-62.

[6] Ramesh B, Reddy PRM, Seenayya G, Reddy G. Effect of various flours on the production of thermostable $\beta$-amylase and pullulanase by Clostridium thermosulfurogenes SV 2. Bioresour Technol 2001; 76: 169-71.

[7] Canganella F, Andrade CM, Antranikian G. Characterization of amylolytic and pullulytic enzymes from thermophilic archaea and from a new Fervidobacterium species. Appl Microbial Biotechnol 1994; 42: 239-45.

[8] Reddy PRM, Reddy G, Seenayya G. Production of thermostable pullulanase by Clostridium thermosulfurogenes SV2 in solid-state fermentation: optimization of nutrients levels using response surface methodology. Bioprocess Eng 1999; 21: 497-503.

[9] Teague WM, Brumm PJ. Commercial enzymes for starch hydrolysis products. In: Schenck FW, Hebeda RE, Eds. Starch hydrolysis products: worldwide technology, production and applications. VCH Publishers, New York, 1992; pp 45-79.

[10] Uhlig H. Industrial enzymes and their applications. WileyInterscience Publication: New York 1998.

[11] Brandt CJ, Catley BJ, Awad WM Jr. Extracellular and proteasereleased pullulanase. J Bacteriol 1976; 125: 501-8.
[12] Ohba R, Ueda S. An inductive effector in production of extracellular pullulanase by Aerobacter aerogenes. Agric Biol Chem 1982; 46: $2425-31$

[13] Miller GL. Use of dinitrosalycilic acid reagent for determination of reducing sugars. Anal Chem 1959; 31: 426-8.

[14] Smith BW, Roe JH. A photometric method for the determination of $\alpha$-amylase in blood and urine with use of the starch-iodine colour. J Biol Chem 1948; 179: 53e.

[15] Gomes I, Gomes J, Steiner W. Highly thermostable amylase and pullulanase of the extreme thermophilic eubacterium Rhodother mus marinus: production and partial characterization. Biores Tech 2003; 90: 207-14.

[16] Takizawa N, Murooka Y. Cloning of the pullulanase gene and overproduction of pullulanase in Escherichia coli and Klebsiella aerogenes. Appl Environ Microb 1985; 49: 294-8.

[17] Antranikian G, Zablowski P, Gottschalk G. Conditions for the overproduction and excretion of thermostable $\alpha$-amylase and pullulanase from Clostridium thermohydrosulfuricum DSM 567. Appl Microbiol Biotechnol 1987; 27: 75-81.

[18] Suzuki Y, Chishiro M. Production of extracellular thermostable pullulanase by an amylolytic obligately thermophilic soil bacterium, Bacillus stearothermophilus KP 1064. Eur J Appl Microbiol Biotechnol 1983; 17: 24-9.

[19] Shinke R, Kunimi Y, Aoki K, Nishira H. Filamentation in Bacillus cereus during $\alpha$-amylase production. J Ferment Technol 1977; 55: 103-10.

[20] Marlida Y, Saari N, Hassan Z, Radu S, Bakar J. Purification and characterization of sago starch-degrading glucoamylase from Acremonium sp. endophytic fungus. Food Chem 2000; 71: 221-27.

[21] Murooka Y, Ikeda R. Biosynthesis and secretion of pullulanase, lipoprotein from Klebsiella aerogenes. J Biol Chem 1989; 264: 17524-31.

[22] Ahmad FB, William PA. Rheological properties of sago starch. J Agr Food Chem 1998; 46: 4060-5.

[23] Ahmad FB, William PA, Doublier JL, Durand S, Buleon A. Physico-chemical characterization of sago starch. Carbohydr Polym 1999; 38: 361-70.

[24] Suraini AA. Sago starch and its utilization. J Biosci Bioeng 2002; 94: 526-9.

[25] Rosfarizan M. Kinetic and modeling of kojic acid fermentation by Aspergillus flavus using different carbon source. PhD Thesis: Universiti Putra Malaysia 2000.

[26] Kamariah L. Production, properties and applications of myceliumbound lipase of a locally isolated strain of Aspergillus flavus link, PhD Thesis, Universiti Putra Malaysia: Malaysia 1997.

[27] dos-Santos VL, Guimaraes WV, de Barros EG, Araujo EF. Fermentation of maltose and starch by Klebsiella oxytoca P2. Biotechnol Lett 1998; 20: 1179-82.

(C) Hii et al.; Licensee Bentham Open.

This is an open access article licensed under the terms of the Creative Commons Attribution Non-Commercial License (http://creativecommons.org/licenses/ by-nc/3.0/) which permits unrestricted, non-commercial use, distribution and reproduction in any medium, provided the work is properly cited. 